\title{
A Study to Understand Reduction Behavior of Toxic Metal in Leachate Using Bentonite
}

\author{
Anupam Kaushik ${ }^{1}$, Dr. Sindhu J. Nair ${ }^{2}$ \\ ${ }^{1}$ M .Tech. Scholar, Environment Science and Engineering, Department of Civil Engineering, \\ BhilaiInstitute of Technology, Durg, Chhattisgarh, India \\ ${ }^{2}$ Professor, Department of Civil Engineering, Bhilai Institute of Technology, Durg, Chhattisgarh, \\ India \\ 므up6652@gmail.com
}

\begin{abstract}
Landfills are the most popular municipal solid waste disposal system. The landfill liner is designed to isolate the waste from the soil beneath to minimize the passage of leachate into the groundwater.Usually, compacted liner materials consist of soil rich in clay minerals for their low hydraulic conductivity. This study is an attempt to assess the use of bentonite as a potential liner material. With the addition of bentonite in landfill liner, the toxicity of leachate is expected to decrease. It was found that bentonite bed works as a shield against percolation of heavy toxic metals from leachate of landfills into soil and groundwater.
\end{abstract}

Key-words:Leachate,bentonite.

\section{Introduction}

In recent years, with the rapid development of urbanization in India, the number of urban population is expanding day by day [1]. As a result, the annual accumulation of municipal solid waste has increased dramatically. In some areas, there has been a phenomenon of "garbage siege” [2, 3]. If not properly handled, it will cause extremely strong pollution to the surrounding environment [4-6]. Sanitary landfills are widely used to treat urban household garbage in India. However, with the development of the economy, there are more and more kinds of urban household garbage, and the pollution is also getting stronger [7, 8]. Because the landfills have their own moisture, and in the long-term erosion of rainwater and groundwater, through the landfills and the overlying soil, it will form a high concentration of wastewater landfill leachate [9]. The composition of the landfill leachate is complex and variable, with uncertainty. Generally, with the high concentration of COD, BOD5, heavy metals, andammonia nitrogen components, this leachate pollution is strong and difficult to deal [10]. If the anti-seepage system of landfills cracks and penetrates, landfill leachate will invade the surrounding environment, and its main hazards include the following aspects: first, it will pollute the surface water and groundwater [11]. India has a large population and a small per capita water supply, making it one of the poorest countries in per capita water resources in the world [12]. Polluted groundwater cannot be used as domestic water source, which will seriously affect people's use of natural resources. Second, it will contaminate the surrounding soil, which cannot be used as farmland or forest land [13]. Moreover, it is difficult to control soil pollution, and it is difficult to achieve results in a short period of time. Also, it will endanger human health. Heavy metal ions in leachate also accumulate in the human body through products in water and plants in soil, which will cause serious social events [14]. To prevent such 
hazardous event, it is important to provide prevention to ground water against leachate. Leachate contains many toxic metals which can mix with ground water. To resolve this problem many methods were tried. Use of bentonite as an inner liner of landfill system is one of the solutions against leachate problem. The present study aims to determine effectiveness of the bentonite against leachate.

\section{Method}

The adsorption performance of the bentonite bed was tested by the self-made adsorption percolation apparatus, as shown in Figure2. The adsorption and retarding properties of the slurry were tested with synthetic leachate in the laboratory. The main components ofsynthetic leachate are shown in Table 1.

Table 1. Composition of Synthetic Leachate

\begin{tabular}{|c|c|}
\hline Components of Leachate & Concentration in $\mathbf{~ m g} / \mathbf{L}$ \\
\hline $\mathrm{Pb}$ & 20 \\
\hline $\mathrm{Cr}$ & 8 \\
\hline $\mathrm{Hg}$ & 2 \\
\hline
\end{tabular}

The basic principle of this method is flow of percolating synthetic leachate through a bed of bentonite as shown in figure 1 . The flow of the leaching solution is kept down-flow as similar to ground conditions. The flow rate is generally accelerated when compared to natural flow conditions. However, it should be slow enough to allow reaction of leachate to bentonite bed. A basis assumption in this test is that the distribution of the leaching solution is uniform and that all particles are exposed equally to the bentonite bed. This experiment is more closely approximate the flow conditions, particle size distribution and pore structure, leachate flow, and solute transport found in the field.After percolation of leachate, its chemical composition is compared with chemical composition of influent synthetic leachate. The adsorption effect of bentonite bed on heavy metal ions reached over $99.80 \%$, which could meet the specified emission requirements. 


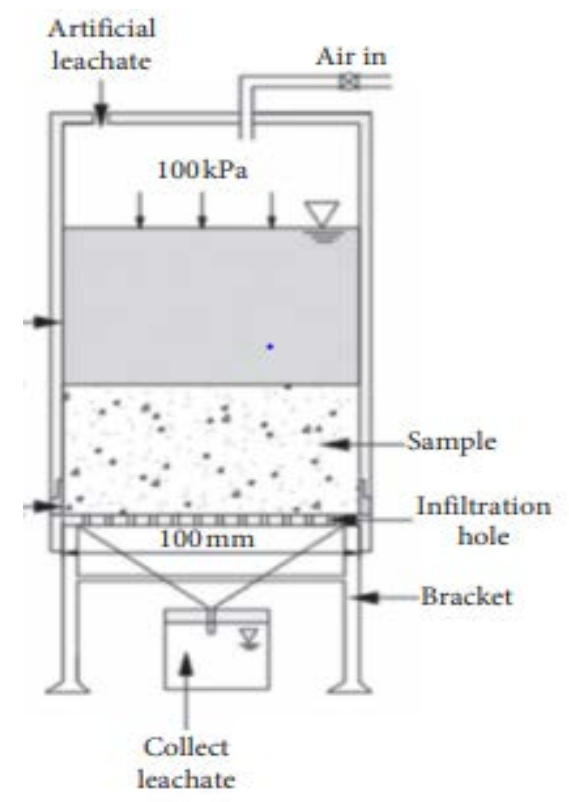

Figure 1. Typical Arrangement of Adsorption Performance Test

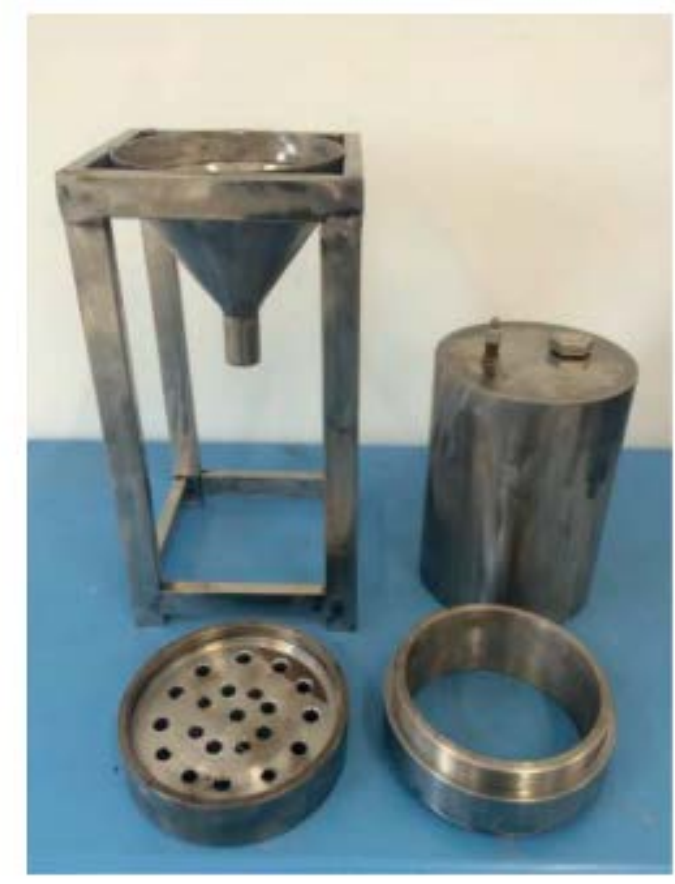

(a) 


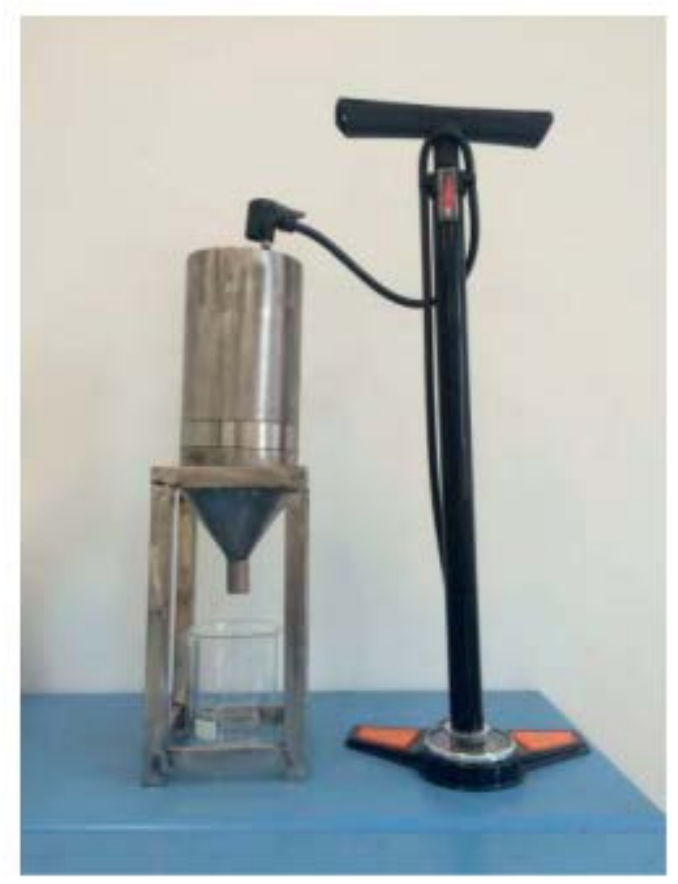

(b)

Figure 2. Laboratory Setup forAdsorption Test

(a) During Dis-Engagement

(b) During Experiment

\section{Result}

The analysis of synthetic leachates after percolation through bentonite bed is as shown in table 2 .

Table2. Leachate Analysis After Percolation Through Bentonite Bed

\begin{tabular}{|c|c|c|c|}
\hline $\begin{array}{c}\text { Component of } \\
\text { Leachate }\end{array}$ & $\begin{array}{c}\text { Concentration } \\
\text { before } \\
\text { percolation in } \\
\mathbf{m g} / \mathbf{L}\end{array}$ & $\begin{array}{c}\text { Concentration after } \\
\text { percolationin } \mathbf{~ m g} / \mathbf{L}\end{array}$ & $\begin{array}{c}\text { Adsorption } \\
\text { Rate }\end{array}$ \\
\hline $\mathrm{Pb}$ & 20 & 0.223 & $98.89 \%$ \\
\hline $\mathrm{Cr}$ & 8 & 0.078 & $99.03 \%$ \\
\hline $\mathrm{Hg}$ & 2 & 0.00025 & $99.98 \%$ \\
\hline
\end{tabular}


Based on above results we can get a effective reduction in concentration of toxic metals in leachate as shown in figure 3.

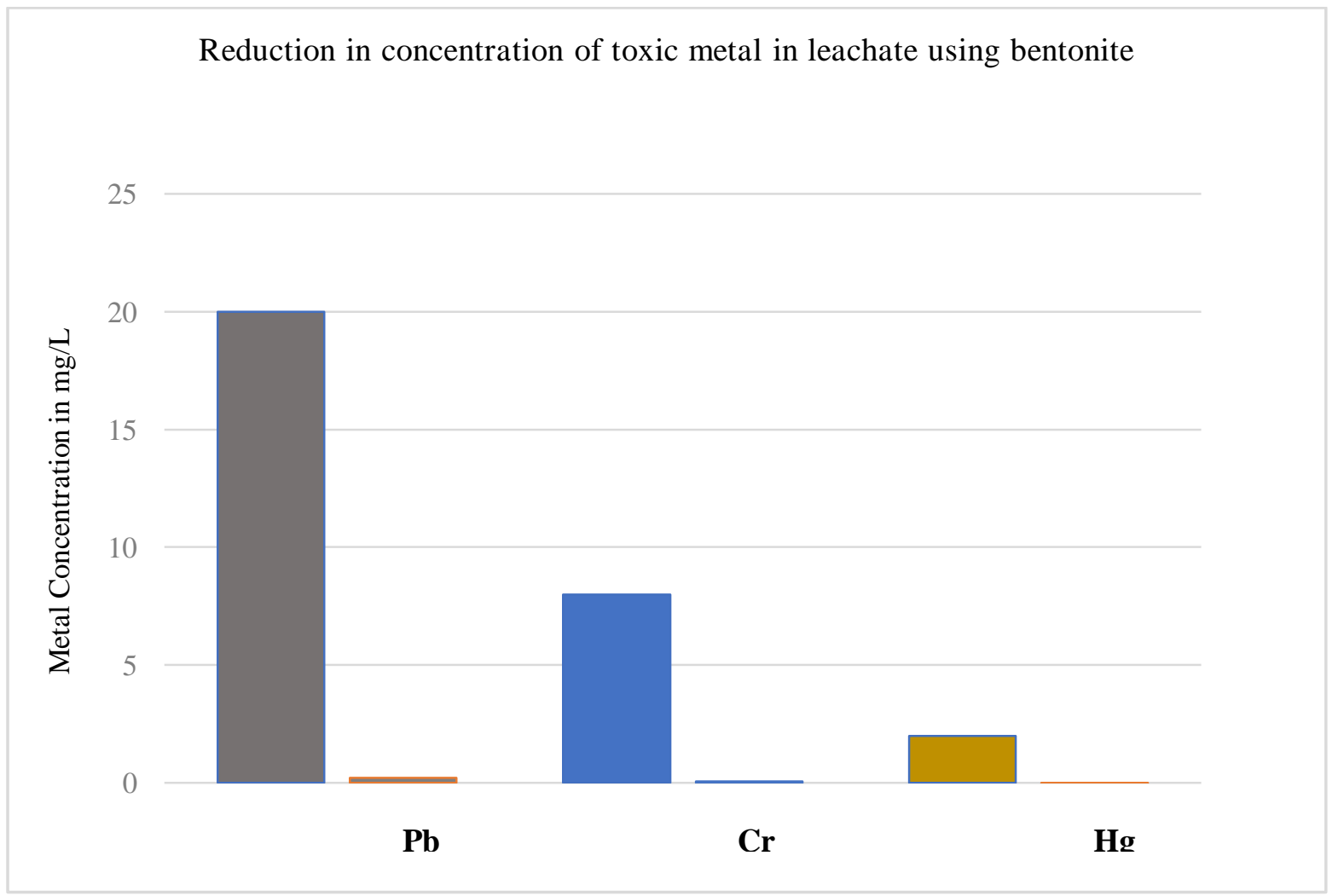

Figure 3.Reduction in Concentration of Toxic Metal in Leachate Using Bentonite

\section{Discussion}

Based on this study and after analyzing of results points are observed:

1. Concentration of toxic metal after percolation through bentonite bed is reduced up to extent of zero.

2. Mercury having highest absorption tendency with bentonite bed among studied toxic metals.

3. Lead having lowest absorption tendency with bentonite bed among studied toxic metals.

4. All metals presented in leachate after percolation through bentonite bed are below the threshold limit. Threshold value for maximum contaminant level is considered as 100 times the allowable limit reported elsewhere [15], [16]. 


\section{Conclusion}

Aftergetting results from this study, it can be concluded that the bentonite bed is an effective mean to minimize toxicity of leachate in landfills. Bentonite bed act as a shield against percolation of heavy toxic metals from leachate of landfills into soil and groundwater. Thus, it should be used as inner liner bed for landfills. Authors of this paper also suggest further study to understand behavior of bentonite bed in respect of strength, leakage, permeability etc.

\section{Acknowledgement}

The author'sgives acknowledgement to laboratory staffs who given their valuable help to perform this study. The author's also gives acknowledgement to various researchers from whom references are taken.

\section{REFERENCES}

[1] D. Khan, A. Kumar, and S. R. Samadder, "Impact of socioeconomic status on municipal solid waste generation rate," Waste Management, vol. 49, (2016), pp. 15-25.

[2] A. J. Chabuk, N. H. M. Al-Ansari, S. Knutsson, and R. Pusch, "Landfill sites selection using analytical hierarchy process and ratio scale weighting: case study of Al-Mahawil, Babylon, Iraq,” Engineering, vol. 9, no. 2,(2017), pp. $123-141$.

[3] G. Liu, Y. Liao, S. Guo, X. Ma, C. Zeng, and J. Wu, “(ermal behavior and kinetics of municipal solid waste during pyrolysis and combustion process,” Applied 4ermal Engineering, vol. 98,(2015), pp. 400-408.

[4] M. Vasi'c, Z. Radojevi'c, Z. Jaǩsi'c, and L. Pezo, "Mathematical "approach to application of industrial wastes in clay brick production - part I: testing and analysis,” Ceramics International, vol. 41, no. 3,(2015).

[5] B. P. Naveen, D. M. Mahapatra, T. G. Sitharam, P. V. Sivapullaiah, and T. V. Ramachandra, "Physicochemical and biological characterization of urban municipal landfill leachate,” Environmental Pollution, vol. 220, no. Pt A,(2016), pp. 112.

[6] J. M. Fernandez-Gonz' alez, A. L. Grindlay, S. Serrano-Ber- ' nardo, M. I. Rodr'lguez-Rojas, and M. Zamorano, "Economic and environmental review of waste-to-energy systems for municipal solid waste management in medium and small municipalities,” Waste Management, vol. 67, (2017), pp. 360-374.

[7] A. Kumar and S. R. Samadder, "A review on technological options of waste to energy for effective management of municipal solid waste,” Waste Management, vol. 69, (2017), pp. 407-422.

[8] J. Hargreaves, M. Adl, and P. Warman, "A review of the use of composted municipal solid waste in agriculture," Agriculture, Ecosystems \& Environment, vol. 123,no. 1-3,(2008), pp. 1-14.

[9] G. Dai, W. Shi, X. Jiang, G. Shi, and Y. Zhang, "Study on the antiseepage mechanism of the PBFC slurry for landfill site," International Journal of Modern Physics B, vol. 31, no. 16-19, (2017). 
[10] R. S. De PaulaCouto, A. F. Oliveira, A. W. S. Guarino, D. V. Perez, and M. R. Da Costa Morques, "Removal of ammonia nitrogen from distilled old landfill leachate by adsorption on raw and modified aluminosilicate," Environmental Technology, vol. 38, no. 7, (2016)pp. 1-38.

[11] R. Zhao, X. Wang, X. Chen, and Y. Liu, “Impacts of different aged landfill leachate on PVC corrosion,” Environmental Science \& Pollution Research, vol. 26, no. 18, (2019), pp. 18256-18266.

[12] Li, C. Shengkui, X. Mei, and M. Liu, "Study on strategies for the sustainable development of China's agricultural resources and environment,” Engineering Sciences, vol. 18, no. 1, (2016), pp. 56.

[13] H. Zhong, Y. Tian, Q. Yang, M. L. Brusseau, L. Yang, and G. Zeng, "Degradation of landfill leachate compounds by persulfate for groundwater remediation,” Chemical Engineering Journal, vol. 307, (2016), pp. 399-40.

[14] A. Montusiewicz, M. Bis, S. Pasieczna-Patkowska, and D. Majerek, "Mature landfill leachate utilization using a costeffective hybrid method," Waste Management, vol. 76,(2018) pp. 652-662.

[15] A. Ghosh and C. Subbarao, "Hydraulic conductivity and leachate characteristics of stabilized fly ash," ASCE J. Environmental Eng., vol. 124, no. 9,(1998), pp. 812-820.

[16] J. S. Gidley and W. A. Sack, “Environmental aspects of waste utilization in construction,” ASCE J. Environmental Eng., vol. 110, no. 6,(1984),pp.1117-1133. 